\title{
Seasonal living and deurbanization: the role of the second home in redistribution of population in large cities of Russia
}

\author{
Ramil Mavlioutov ${ }^{1 *[0000-0001-5920-1331]}$ and Mikhail Belyaev ${ }^{1 \text { [0000-0001-6018-1024] }}$ \\ ${ }^{1}$ Volgograd State Technical University, 400005, Lenin avenue, 28, Volgograd, Russia
}

\begin{abstract}
The dacha community, as a characteristic phenomenon of Russian reality, increases its importance in the redistribution of the population in large cities of Russia. The dacha as a place of the seasonal living is transforming into the first home. The study of the genesis of the dacha community has established that nowadays, having transformed into a partnership of real estate owners, it has gained the potential to intensify the process of deurbanization of a large city through the transformation of its social, economic, communal-infrastructural and ecological subsystems. The article offers to introduce zoning of the location of dacha cottages from the point of view of geography. This zoning is based on transport services: a city, a neighbouring suburb, a distant suburb. The sample survey of 25 dacha communities in Volgograd with its suburbs and their grouping allowed to find out the following fact: those ones which are located in the border areas of the city and in the neighbouring suburbs have the greatest potential in transforming the dacha into the place of permanent home and promoting deurbanization.

Keywords: dacha community, dacha, large city, suburb, dezurbanization, the second home, steady development, partnership of real estate owners.
\end{abstract}

\section{Introduction}

The problem of stability is one of the fundamental problems of natural science. The concept of environmental sustainability finds its place in various fields of science and fields of activity, including economics [1-4], geography [5-7], urban planning [8-10]. At the same time, the sustainability of the environment is not an aim itself; its efficiency, which manifests itself in the process of the development of the environment, is at the forefront. In turn, the effectiveness of the environment is achieved by its assistance to the successful functioning of the system and the achievement of its goals. In the context of the postindustrial transition, the spatial development of Russia is largely determined by the development of large cities, the number of which in 2021 is 15 . These are federal cities of Moscow and St. Petersburg with a population of 12.7 million and 5.4 million people respectively, as well as cities with the population of 1-2 million people (Novosibirsk, Yekaterinburg, Nizhny Novgorod, Kazan, Chelyabinsk, Omsk, Samara, Rostov-on-Don,

* Corresponding author: ramil-2002@mail.ru 
Ufa, Krasnoyarsk, Perm, Voronezh, Volgograd). At the same time, a significant part of the territory of these cities, as well as suburban areas are made up of horticultural partnerships, which date back the period of Soviet Russia in the middle of the 20th century. By inertia they are called dacha communities, and some of the land with buildings is called dachas. The number of dacha communities reaches 80 thousand and unites over 50 million citizens of Russia.

The COVID-19 pandemic that swept the world and Russia in the early 2020 presented the new vision of the issue of the functional purpose of dacha communities. During 2020, they began to be interpreted as a place of recreation with a priority towards the status of a place of permanent residence, although earlier dacha communities were considered as the second home, housing for seasonal use. The need for lockdown, which is difficult to achieve in the city under conditions of close social interaction, is easy to carry out living in the dacha. This fact has increased the interest in dacha communities and has also increased demand for suburban real estate, which led to its rise in price on average in Russia by the end of 2020 by $11 \%$, and in some regions of Russia by a third.

Thus, we should talk about the intensification of the transformation of the functional purpose of dachas, the direct consequences of which are deurbanization, a change of the geography of the resettlement of labour resources with a simultaneous transformation of the subsystems of a large city. This, in turn, increases the impact of a complex of force majeure factors that have a direct impact on the sustainable development of large cities.

Deurbanization, first implemented in practice by the architects Taut BJF, Wright FL [11], has become widespread as a direction in urban planning. A significant number of scientific publications are devoted to this issue, both of a conceptual nature [12-16] and describing practice in individual states, groups of countries such as the USA, Germany, Poland, Japan, South Africa [17-21]. At the same time, only a small number of works investigate the settlements that combine the second home. Among them there are works devoted to cottage settlements in Ukraine [22] Slovenia [23] and Estonia [24], as well as seasonal housing in Finland [25], which are of interest due to the commonality during the period of socialist development. At the same time, there are no works examining Russian dacha communities, taking into account the growing processes of labour migration, digitalization of society, and the context of the COVID-19 pandemic.

In the context of the transformation of dacha communities, the need to study the current state of the issue of ensuring the sustainable development of large cities in Russia has emerged, which determines the relevance of the study and the research task. The aim of the study is to determine further ways of dacha transformation in the context of ensuring the sustainable development of large cities in Russia. This aim is based on the studying the evolutionary development of the dacha movement, organizationally taking the form of a partnership of real estate owners. The object of the research is dacha community located on the territory and in the suburbs of large cities of Russia.

\section{Materials and methods}

The study is based on the practice of the functioning of suburban settlements located both on the territory of 15 large Russian cities and within their suburbs. Changes in the normative legal regulation of the functioning of dacha communities, which are in line with the transformation of the economic model of the Russian state, the change in the functional purpose of dacha communities is intensified by the global processes. These processes require a deep comprehensive study, which, within the framework of this study, was carried out from the standpoint of those that received an impetus for the active development of the tendencies of deurbanization of large cities in Russia. At the same time, due to the lack of official statistics, the information base of the study was made up of materials of free access 
to the Internet, analytical agencies, and construction companies. Also, the normative legal acts of the USSR, the RSFSR, and the Russian Federation were used.

Achievement of the aim of the study is based on the use of the following methods: analysis, synthesis, historical method, grouping, classification, economic analysis.

\section{Results}

The dachas in their current form are the legacy of the Soviet era although the origin of the term dates back to the period of the reign of Peter the Great. The tsar gave his entourage the land for the arrangement of temporary buildings near the newly built St. Petersburg. These buildings in everyday life began to be called dachas in everyday life. Since then, they began to be considered exclusively as temporary housing outside the city. Dachas have undergone a radical evolutionary transformation, primarily from the standpoint of functional purpose, incentive for disposal and ownership. And if in the period of the USSR the basis of their definition was directive regulation by the state, then in the period of modern Russia over the past 30 years, state regulation has faded into the background, making room for the needs of citizens, based on considerations of economy and rationalism. The legal basis necessary for the formation of mass participation of citizens in horticultural partnerships was founded in the first half of the 1950s. The model charters in 1956, 1985 and 1988 detailed the organization and functioning of horticultural associations, which acted in the status of consumer cooperatives. They were organized on the basis of land specially issued to enterprises, organizations and institutions. Membership in the partnership was a confirmation of the provision of land to a citizen. In 1991 the ownership of land was legalized. In 2001, the possibility of permanent (indefinite) use and lifelong inheritable ownership of plot was abolished. The latter caused the need to re-register the rights to land plots; for about 20 years, the period for registration in a simplified manner of plots of members of horticultural partnerships has been repeatedly extended. The last renewal period expires in March 2026.

In the 1960s-1980s the functional purpose and the incentive for use of dacha was to overcome the shortage of high-quality food products. The peak of this purpose was in the 1990s with the collapse of the collective far movement. In the first decade of the XXth century dacha communities gained a renewal due to the fact that they became an object of recreation, rest, change of scenery. Here, auxiliary production has become rather a pleasant hobby, but not at all an obligatory pastime. Over the past decade, we can observe the third stage of the horticultural movement, when the dacha begins to actively implement its housing function. The growth of this process led to an active public discussion of the issue of acquiring the status of a settlement by dacha communities (as part of an existing one or through the formation of a new one). In this regard, we should talk about the acquisition of a dacha of a new meaning. The regulation of the organization and functioning of dacha communities has been adapted according to the change in society, the growth of its demands (see Table 1).

Thus, the 1956 charter prescribes the task of organizing a horticultural partnership, which consists in meeting the needs for fruit and berry products and organizing recreation. The 1985 charter establishes the practice of growing any agricultural product that was already established at that time. It is noteworthy that during that period a direct ban was introduced on «money-grubbing, construction of mansions». At the same time, a direct indication that it is possible to build exclusively summer houses with one floor is introduced according to standard projects with a heated room up to $25 \mathrm{~m}^{2}$, an unheated terrace up to $10 \mathrm{~m}^{2}$ and an unheated attic up to $15 \mathrm{~m}^{2}$. The 1988 edition of the standard charter allows the construction of heated houses according to standard or individual 
projects with an area of up to $50 \mathrm{~m}^{2}$, and there are no restrictions on the construction of other buildings.

Table 1. Possibility of construction of a dwelling-house on the land of a dacha community.

\begin{tabular}{|c|l|}
\hline $\begin{array}{c}\text { Period } \\
\text { of time }\end{array}$ & \multicolumn{1}{c|}{ Possibility of construction of a dwelling-house } \\
\hline $1955-1988$ & Typical house \\
\hline $1985-1988$ & $\begin{array}{l}\text { A house of standard project with heated room up to } 25 \mathrm{~m}^{2} \text {, unheated attic up } \\
\text { to } 15 \mathrm{~m}^{2}\end{array}$ \\
\hline $1988-1998$ & A heated house of standard or individual project up to $50 \mathrm{~m}^{2}$ \\
\hline $1998-2017$ & A house with no right of registration; a house with right of registration \\
\hline $\begin{array}{c}2017-\text { till } \\
\text { today }\end{array}$ & $\begin{array}{l}\text { Dwelling-house, summer house is a detached building, no more than of three } \\
\text { floors and no more than of } 20 \text { meters high, which is not intended to be } \\
\text { divided into independent real estate objects }\end{array}$ \\
\hline
\end{tabular}

Until recently, Federal Law No. 66-FL [26] provided for three organizational and legal forms of associations of citizens: non-commercial partnership, cooperative retail societies, non-commercial partnership. Each of them, depending on the intended purpose of the lands united by it, could be accompanied by the epithet characterizing it «horticultural». In this case, we are not interested in the resulting primary purpose of the sought sites, but in the possibility of construction dwelling-buildings (dwelling-houses) on them. On the dacha land, it was allowed to construct a dwelling-building without the right to register residence. On some land, the construction of non-capital residential buildings was allowed, which a priori excluded the possibility of obtaining registration of residence on it. And only the owners of dachas were allowed, along with the construction of a residential building without the right to register residence, to build a residential building with the right to register residence.

Federal Law No. 190-FL [27] defines a detached building (in other words, an object of individual housing construction or an individual housing construction object) as a building with no more than three floors and no more than 20 meters in height. Moreover, this building is not intended to be divided into independent real estate objects, as a residential building.

Within the current legal framework, Federal Law No. 217-FL [28] allows the existence of two organizational forms of organizing citizens for horticulture: a horticultural noncommercial partnership (SNT in Russian transcription) and a gardening non-commercial partnership (ONT in Russian transcription). Both of these forms are types of real estate partnerships (TSN in Russian transcription). It is allowed to construct the dwellingbuildings on the land of these partnerships. At the same time, the features of the latter are identical to those established by the City Planning Code in relation to the dwellingbuildings (objects of individual housing construction). At the same time, the law approved the procedure for recognizing a garden house as residential (and vice versa), which in fact is of a declarative nature.

Thus, now horticultural partnerships have transformed into SNT as a type of partnership of real estate owners. Thus, the need was formed to interpret the dacha not as an object for temporary use, but as an object of property with all the ensuing rights and obligations.

TSN is created on a voluntary basis. It unites the owners of real estate. Its purpose is owning joint ownership. It uses property that is in common ownership. Common property belongs to the TSN members (or the owners of land) by the right of common shared ownership. Here TSN provides the ability to centralize the management of all real estate, which allows rationalizing the management and disposal of common property objects. In addition, in this case, it is possible to conduct economic activities in the interests of TSN members (for example, renting out common property). 
There is no exact information on the number of dacha settlements, as well as on the number of their members. Due to the fact that objects of individual housing construction are legally allowed to be constructed on the territory of land of SNT, but not on the land of ONT, it is the first ones that should be considered as potential territories of newly created settlements or territories that can be attributed to existing ones.

From the point of view of geography, it is proposed to introduce the zoning of the location of dacha communities as follows:

- dacha communities which are located within the city;

- dacha communities which are located in the nearest suburbs;

- dacha communities which located in the distant suburbs.

At the same time, the allocation of the near and distant suburbs is based on the zoning of transport services. The nearest suburb is characterized by the presence of fixed-route taxis and buses. The distant suburb is characterized by buses and routed taxis of a seasonal nature, regular buses, electric trains of suburban communication.

In September and November 2020, a survey of 25 dacha communities was carried out for the provision of communal infrastructure. Based on its results, four groups of dacha communities were identified:

group 1: dacha communities are located within the city, near its central part;

group 2: dacha communities are located within the city, near its administrative boundaries;

group 3: dacha communities are located in the near suburbs, near the administrative boundaries of the city;

group 4: dacha communities are located in the far suburbs, more than 10 kilometers from the administrative boundaries of the city.

Typical representatives were identified for each of these groups. Two of them are located in the city of Volgograd (SNT «40 Let Oktyabrya», SNT «Gornopolyanets»), one is located in the near suburb of Volgograd (SNT «Neftepererabotchik»), one is located in the distant suburb of Volgograd (SNT «Siren»). The survey results are shown in Table 2. In addition, a sociological study was carried out, the purpose of which was to identify the constraining factors so that a dwelling- building located on the territory of a horticultural partnership became the first housing. The respondents were the owners of dwellingbuildings who are participants in the surveyed SNTs. Within the information of Table 2, while determining the distance, the reference point was taken to be the zero kilometer of roads in the Volgograd region. This reference point is located in the centre of Volgograd on the Square of Fallen Fighters.

So, all the surveyed SNTs have a centralized power supply. Only one has a centralized water supply (SNT «40 let Oktyabrya»), which is caused by its location within the city among the existing mass dwelling-buildings. Along with the latter, the centralized gas supply is available in one more dacha community (SNT «Gornopolyanets»).

All dacha communities have got the autonomous drainage. Thus, the belonging of the dacha community to the city increases the provision of communal infrastructure, it is at the maximum in SNT «40 let Oktyabrya» which has the smallest distance from the city. If water supply and drainage can be organized in an autonomous use mode, so the lack of centralized gas supply imposes an almost insurmountable restriction on the use of residential buildings on the territory of a dacha community as the first home. This is due to the need to provide heating for at least six months throughout the year. Thus, year-round living in a dwelling-building should be ensured, which in turn will make it possible to issue permanent registration. At the same time, heating by means of electric energy is expensive and, in general, from an economic point of view, it is inexpedient. For example, heating a dwelling-building with an area of 180 square meters using electric energy in the winter season costs up to 15 thousand rubles monthly. At the same time, the cost of connecting to 
a centralized gas supply network varies significantly: if for SNT «Gornopolyanets» it is equal to 250 thousand rubles, then for SNT «40 let Oktyabrya» it is already equal about 500 thousand rubles. For SNT «Neftepererabotchik», gasification is planned in the medium term, and for SNT «Siren», it is completely beyond any plans.

Table 2. Results of a survey of dacha communities for the provision of communal infrastructure.

\begin{tabular}{|c|c|c|c|}
\hline Group & Title & $\begin{array}{c}\text { Characteristics of the geographical } \\
\text { location, remoteness }\end{array}$ & State of infrastructure \\
\hline 1 & $\begin{array}{l}\text { SNT «40 let } \\
\text { Oktyabrya» }\end{array}$ & $\begin{array}{l}\text { It is situated in the boundaries of the city } \\
\text { of Volgograd. At its beginning, in the } \\
1950 \mathrm{~s} \text {, was the part of Volgograd } \\
\text { outskirts; during the process of the city } \\
\text { development became the part of the city } \\
\text { near its centre. Remotenessis } 11 \mathrm{~km} \text {. }\end{array}$ & $\begin{array}{l}\text { Power supply is } \\
\text { centralized, water } \\
\text { supply is centralized, } \\
\text { gas supply is } \\
\text { centralized, } \\
\text { Drainage } \\
\text { systemisautonomous. }\end{array}$ \\
\hline 2 & $\begin{array}{c}\text { SNT } \\
\text { «Gornopolyanets» }\end{array}$ & $\begin{array}{l}\text { It is situated in the boundaries of the city } \\
\text { of Volgograd. At its beginning, in the } \\
1990 \mathrm{~s} \text {, this SNT was the part of } \\
\text { Gorodishcheskiy district of Volgograd } \\
\text { region. In } 2006 \text { it became the part of } \\
\text { Volgograd. Remoteness is } 33 \mathrm{~km} \text {. }\end{array}$ & $\begin{array}{l}\text { Power supply is } \\
\text { centralized, water } \\
\text { supply is autonomous, } \\
\text { gas supply is } \\
\text { centralized, } \\
\text { drainageisautonomous }\end{array}$ \\
\hline 3 & $\begin{array}{c}\text { SNT } \\
\text { «Neftepererabotchik» }\end{array}$ & $\begin{array}{l}\text { It is situated in the nearest suburb of the } \\
\text { city of Volgograd. Remotenessis } 39 \mathrm{~km} \text {. }\end{array}$ & $\begin{array}{l}\text { Power supply is } \\
\text { centralized, water } \\
\text { supply is autonomous, } \\
\text { gas supply is } \\
\text { autonomous, } \\
\text { drainageisautonomous }\end{array}$ \\
\hline 4 & SNT «Siren» & $\begin{array}{l}\text { It is situated in the distant suburb of the } \\
\text { city of Volgograd. Remotenessis } 43 \mathrm{~km} \text {. }\end{array}$ & $\begin{array}{l}\text { Power supply is } \\
\text { centralized, water } \\
\text { supply is autonomous, } \\
\text { gas supply is } \\
\text { autonomous, } \\
\text { drainageisautonomous }\end{array}$ \\
\hline
\end{tabular}

Thus, the full access to communal infrastructure is organized only in the dacha community within the city of Volgograd. The dacha communities of the near suburb have only partial access with the potential to get full access, and the dacha communities within the distant suburb do not have the opportunity to organize it in the near future. Therefore, the main driving force of the transformation of the second home into the first one should be the dacha communities located in the border areas of the city and in the nearby suburbs. The availability of social infrastructure also confirms this fact. The provision of citizens living in the city and, due to easy transport accessibility in the near suburb, with the services of medical institutions, preschool and school education institutions, creates a competitive advantage for dacha communities located on their territory over those in a distant suburb. All this is confirmed by the practice that has developed over the past 15 years. The dwelling-houses of the dacha communities on the territories close to the city center (group 1) become places of permanent residence, both in fact and from a legal point of view (permanent registration). Dacha communities which belong to group 4, in the medium term, will continue to be representatives of seasonal housing, as was originally planned. The dwelling-buildings on the territory of dacha communities of groups 2,3 become potential sources of activation of the deurbanization of a large city.

At the same time, the most owners of dachas are considering the possibility of using their existing dwelling-buildings as their first home, even if they have a flat in the city. However, $72 \%$ of the respondents said that the main limiting factor is the insufficient 
infrastructure provision of dacha buildings(first of all, this factor is heating, water supply and drainage are less important factors). In thesecond place or $45 \%$ is the low provision of social infrastructure (medical care, preschool and school education institutions). In these conditions, the owners of land have a desire to join the SNT within the boundaries of the settlement. They consider this as the easiest way to solve infrastructure problems.

According to the Association of individual dwelling construction, the volume of the individual housing construction market in Russia at the moment is 550 billion rubles, with prospects of threefold growth until 2022. Such an optimistic forecast is due to the following factors. The share of individual housing construction in the total volume of housing commissioned accounts for $40 \%$, and the share of mortgage lending in the composition of sources of financing for individual housing construction is $1 \%$.

For construction of flats, this figure exceeds $80 \%$ [29]. Here, positive developments should be noted. Since the first of December 2020, a pilot program of preferential mortgage lending for individual housing construction for families with children was launched. For the period until the thirtieth of June, 2021, it is planned to issue loans for 2.2 billion rubles.

The experience of performing a labour function outside the employer's location, accumulated during 2020 in the context of the COVID-19 pandemic, as well as systematizing the legislative regulation of teleworking (remote work), make a positive contribution to the deurbanization process. As part of a large-scale study of the principles of organizing remote work by Russian businesses in 2020, it was found that $84 \%$ of companies find benefits for both business and employees. So, the attractiveness of dacha communities as a place of permanent residence and performance of a labor function, both within a large city and regions increases.

Another incentive to change the permanent place of residence is the unfavorable natural and ecological situation in large cities. Most large cities are industrial centres that are burdened with a legacy of industrialization. In the current conditions of the post-industrial transition, enterprises as sources of environmental pollution are increasing their environmental friendliness and are gradually being pushed out of large cities. This is an irreversible process, the result of which is a gradual improvement of the city's ecology. At the same time, the growth in the well-being of citizens, in many respects the imposition of a consumer culture over the past 20 years has led to an intensive increase in the provision of Russians with a personal car. For the period of 2000-2020 this indicator has more than doubled from 130 to 310 on average in Russia and from 120 to 260 in Volgograd. This has made road transport emissions the main source of environmental pollution in most large cities.

In general, moving from a large city outside its boundaries or in the vicinity of its administrative boundaries has two interrelated effects.

First, the environmental situation in the city is reduced, and it is transferred to the outskirts. First of all, this is caused by a shift in the area of the use of personal road transport, both due to a change in the place of permanent residence, and in some cases due to the organization of work in a remote format. Further, the reasons of the second level should be mentioned. These reasons are decrease in the load on the district heating systems with a corresponding decrease in their consumption of energy carriers (primarily gas) and a decrease in toxic emissions into the atmosphere; a decrease in the volume of municipal solid waste and a corresponding decrease in the need for their transportation to disposal sites; general reduction of technogenicaccidents.

Secondly, the environmental friendliness of the place of residence of citizens and the quality of their life increase. This is primarily due to the remoteness from a large city which is the place of concentration of pollution sources. Here we should talk about a decrease in the level of pollution of air, surface water, soil, and a decrease in noise. All this, in the long term, provides a basis for increasing the ability to work and raising the quality of 
performance of labour functions, increasing fertility, and increasing life expectancy. The improvement of the demographic situation in the strategic plan will act as the engine of growth at the macro level of the entire Russian economy.

Thus, we should talk about the intensification of the transformation of the functional purpose of horticultural partnerships, the direct consequences of which is a change in the geography of the resettlement of labour forces with the simultaneous transformation of three subsystems of a large city such as socio-economic, communal-infrastructural, natural and ecological ones.

However, an important obstacle stands in the way of realizing this potential: the vicious perception by citizens of their status of owning a land. It developed back in the Soviet period, when land, due to the objective absence of private property, were legally «fixed for unlimited use», which did not exclude its loss due to violation of the requirements of the charter of a partnership. The legalization of the ownership of land in 1991 for 30 years shows a picture when about 1 million land plots of dacha communities have not yet been registered in ownership. This is one of the testimonies of the mistaken perception of the disposal of property objects that has formed among Russian citizens. Land is identified as fixed, donated, namely «dachas» in the original sense of the word. But not as a full-fledged property, which, however, stems from the legal status of dacha communities, namely a partnership of real estate owners. And the status of the owner imposes, along with the ability to use the object, the obligation to maintain it in proper condition. This, among other things, includes responsibility for the formation and further development of the TSN infrastructure as a common property. Without this, the transition of the dacha community to a qualitatively new level namely to the territory of comfortable living will be impossible. Objectively, the dependent position in this case is the main deterrent to the realization of the potential of the dacha community as a place of mass permanent residence of Russian citizens.

\section{Discussion}

A study of dacha communities over the past 70 years allows us to conclude that, in their current form, they have lost their original purpose. If in the Soviet period it was the satisfaction of non-material needs, which consists in strengthening health, organizing cultural recreation, leisure of citizens, while the goal of providing the family with food was in the background. Although in practice the latter was dominant. This allows us to characterize economic incentives in this way the driving force behind the ownership of a dacha in the period up to the beginning of the 2000s. Recently, the ownership of land and the corresponding membership in the partnership of real estate owners has been focused on resolving issues of predominantly material, practical meaning. Namely, this is the effective management of common property, land, maintenance in the proper condition of the territory.

Over the past ten years there is an increase in the pace of individual housing construction, which involves the identification of residential buildings under construction (or the reconstruction of previously constructed buildings to bring them the requirements of the Housing Code for residential buildings). Thus, the buildings on the dacha territoryare intended not for seasonal, but for year-round living. We can talk about the issues of improvement of the territory of the dacha communities, improving the comfort of living, providing with infrastructure, socialization and greening.

The study of the place and role of dacha settlements in the deurbanization of large cities in Russia using the example of Volgograd showed that SNTs which are located near city administrative boundaries and in the near suburbs have the greatest potential. Optimal provision of communal and social infrastructure is observed here. At the same time, the 
process of deurbanization causes the transformation of the subsystems of a large city: socioeconomic (change in the geography of the resettlement of labour forces, the performance of a labor function in a remote format, an increase in labour productivity, an improvement in the demographic situation); communal infrastructure (reducing the load on the housing and communal infrastructure, road network); natural and ecological (reduction of toxic emissions, conservation of biodiversity).

The next step in the movement to transform dacha communities may be joining an existing settlement. Another way to implement this tendency should be the currently actualized mechanism for obtaining SNT the status of a settlement. This legislative base of this is being developed by the State Duma and the Union of Russian Gardeners. Its practical implementation will entail the need for a systematic scientific, regulatory, legislative study of the complex of issues facing society. This process should be implemented in close connection, interaction of scientific, legislative fields with practitioners and the dacha community.

\section{References}

1. F. Merino, M. A. Prats, Why do some areas depopulate? The role of economic factors and local governments, Cities, 97 (2020) DOI: 10.1016/j.cities.2019.102506

2. P. N. Ao, COVID, cities and climate: Historical precedents and potential transitions for the new economy, Urban Science, 3 (2020) DOI: 10.3390/urbansci4030032

3. D. M. Iwaniec, E. M. Cook, M. J. Davidson, M. Berbes-Blazquez, M. Georgescu, E. S. Krayenhoff, A. Middel, D. A. Sampson, N. B. Grimm, The co-production of sustainable future scenario, Landscape and Urban Planning, 197 (2020) DOI: 10.1016/j.landurbplan.2020.103744

4. O. Novikova, O. Khandii, L. Shamileva, Socio-economic risk assessment and peril analysis in the context of the COVID-19 pandemic and emergencies, European Journal of Sustainable Development, 10 (2021) DOI: 10.14207/ejsd.2021.v10n1p636

5. F. Ahmadzai, Analyses and modeling of urban land use and road network interactions using spatial-based disaggregate accessibility to land use, Journal of Urban Management, 3 (2020) DOI: 10.1016/j.jum.2020.06.003

6. S. Schindler, J. M. Kanai, Producing localized commodity frontiers at the end of cheap nature: An analysis of eco-scalar carbon fixes and their consequences, International Journal of Urban and Regional Research, 42 (2018) DOI: 10.1111/1468-2427.12665

7. W. A. Aboneama, Applying sustainable development in architecture, planning and infra-structure of Abha to be the first eco-city in the Middle East, European Journal of Sustainable Development, 7 (2018) DOI: 10.14207/ejsd.2018.v7n4p289

8. C. Culwick, Z. Patel, Building just and sustainable cities through government housing developments. Environment and Urbanization, 32 (2020) DOI: $10.1177 / 0956247820902661$

9. F. Van Noorlooso, Incremental housing as a node for intersecting flows of citymaking: rethinking the housing shortage in the global South, Environment and Urbanization, 32 (2020) DOI: 10.1177/0956247819887679

10. E. Szafranska, L.C. de Lille, J. Kazimierczak, Urban shrinkage and housing in a postsocialist city: relationship between the demographic evolution and housing development in od, Poland, Journal of Housing and the Built Environment, 34 (2019) DOI: $10.1007 /$ s10901-018-9633-2

11. F. Caprotti, The New Urban Agenda: key opportunities and challenges for policy and practice, Urban Research \& Practice, 10 (2017) DOI: 10.1080/17535069.2016.1275618

12. F. L. Wright, An Autobiography (Duell, Sloan and Pearce, New York, 1943) 
13. A. T. Salaj, C.M. Lindkvist, Urban facility management. Facilities, 12 (2020) DOI: 10.1108/F-06-2020-0078

14. G. Bosworth, H. Bat Finke, Commercial counterurbanisation: A driving force in rural economic development. Environment and Planning 52 (2020) DOI: 10.1177/0308518X19881173

15. B. Ioannou, L. Nicolaou, K. Serraos, G. Spiliopoulou, Large urban developments as non-planning products: Conflicts and threats for spatial planning, Urban Planning, 4 (2019) DOI: 10.17645/up.v4i4.2266

16. E. C. Escobar, M. G. González, C. M. Quintero, Trends and paradigms on the organization of rururban spaces: A theoretical approach, Ciudad y Territorio Estudios Territoriales, 50 (2018)

17. B. J. L. Berry, Urbanization and counter-urbanization in the United-States, Annals of the American Academy of Political and Social Science, 451 (1980) DOI: $10.1177 / 000271628045100103$

18. U. Engfer, Retirement migration and reurbanisation trends in Germany 1995-2012, Raumforschung und Raumordnung-Spatial Research and Planning, 76 (2018) DOI: 10.1007/s13147-017-0513-0

19. C. Kowalczyk, J. Kil, K. Kurowska, Dynamics of development of the largest cities Evidence from Poland, Cities, 89 (2019) DOI: 10.1016/j.cities.2019.01.018

20. S. Buhnik, The dynamics of urban degrowth in Japanese metropolitan areas: What are the outcomes of urban recentralisation strategies? Town Planning Review 88 (2017) DOI: $10.3828 /$ tpr.2017.7

21. N. P. Geyer, Counterurbanization in South Africa: Measuring migration significance. Regional Science Policy and Practice, 10 (2018) DOI: 10.1111/rsp3.12105

22. I. G. Savchuk, S. P. Zapototskyi, Cottage settlements in capital region of Ukraine, Journal of Geology Geography and Geoecology, 29 (2020) DOI: 10.15421/112037

23. S. Drobne, A. Z. Lamovsek, Functional urban areas as instruments of spatial development policy at the regional level in the case of Slovenia, Prostor, 25 (2017) DOI: $10.31522 / \mathrm{p} .25 .2(54) .3$

24. L. Pungas, Food self-provisioning as an answer to the metabolic rift: The case of «Dacha Resilience» in Estonia, Journal of Tural Studies, 68 (2019) DOI: 10.1016/j.jrurstud.2019.02.010

25. C. Adamiak, K. Pitkänen, O. Lehtonen, Seasonal residence and counterurbanization: the role of second homes in population redistribution in Finland, GeoJournal, 82 (2017) DOI: 10.1007/s10708-016-9727-x

26. Federal Law of April 15, 1998 No. 66-FL, URL: www.consultant.ru (last accessed: 22.03.2021)

27. Federal Law of December 29, 2004 No. 190-FL, URL: www.consultant.ru (last accessed: 22.03.2021)

28. Federal Law of July 29, 2017 No. 217-FL, URL: www.consultant.ru (last accessed: 22.03.2021)

29. R. Mavlioutov, E. Egorova, O. Pakhomova, Financial maintenance of building of affordable housing on the basis of public-private partnership, Materials Science Forum: Materials and Technologies in Construction and Architecture, 931 (2018) DOI: 10.4028/www.scientific.net/MSF.931.1107 